\begin{tabular}{cc|c}
\hline Tar. Bil. Der. & Journal of Agricultural Sciences \\
& $\begin{array}{c}\text { Dergi web sayfası: } \\
\text { www.agri.ankara.edu.tr/dergi }\end{array}$ & Journal homepage: \\
& www.agri.ankara.edu.tr/journal
\end{tabular}

\title{
Effect of Environment and Genotype on the Protein Quality Attributes and Baking Characteristic of Newly Developed Wheat Inbred Lines
}

\author{
Noha I. A. MUTWALI ${ }^{\mathrm{a}}$, Abdelmoniem I. MUSTAFA ${ }^{\mathrm{a}}$, Isam A. Mohamed AHMED ${ }^{\mathrm{a}, \mathrm{b}}$, Elfadil E. BABIKER \\ ${ }^{a}$ University of Khartoum, Faculty of Agriculture, Department of Food Science and Technology, Shambat 13314, Khartoum, SUDAN \\ ${ }^{\boldsymbol{b}}$ King Saud University, College of Food and Agricultural Sciences, Department of Food Science and Nutrition, Riyadh 11451, KINGDOM of \\ SAUDI ARABIA
}

\section{ARTICLE INFO}

Research Article DOI: 10.15832/ankutbd.446407

Corresponding Author: Elfadil E. BABIKER, E-mail: ebabiker.c@ksu.edu.sa, Tel: +966 (11) 4678394

Received: 10 October 2015, Received in Revised Form: 06 April 2017, Accepted: 17 April 2017

\begin{abstract}
The present work examined the effect of genotype and environment on protein content and fractions, gluten and starch fraction, SSL (sodium stearoyl-2-lactylate) and DMG (distilled mono glyceride) binding ability of starch and specific loaf volume (SLV) of six wheat genotypes grown in three different environment. Genotype and environment significantly affected all quality attributes under investigation. However, protein content and fractions showed differences in relative effects of genotype and environment. Most of the protein quality characteristics were influenced more by genotype than environment. Size distribution of gluten subunits was significantly affected by genotype and environment. It was observed that as the flour protein content increased, the magnitudes of monomeric proteins appeared to rise, but glutenin decreased. Flour protein content was expressively associated with gliadin and dough making characteristics. Environment influenced both the amounts of total protein and the quantities of different protein fractions, which, in turn, influenced baking quality.

Keywords: Wheat genotypes; Loaf volume; Electrophoresis; Molecular weight; Protein; Starch
\end{abstract}

\section{Kendileme ile Geliştirilmiş Yeni Buğday Hatlarının Protein Kalitesi ve Ekmeklik Özelliklerine Çevre ve Genotipin Etkisi}

\section{ESER BILLGISİ}

Araştırma Makalesi

Sorumlu Yazar: Elfadil E. BABIKER, E-posta: ebabiker.c@ksu.edu.sa, Tel: +966 (11) 4678394

Geliş Tarihi: 10 Ekim 2015, Düzeltmelerin Gelişi: 06 Nisan 2017, Kabul: 17 Nisan 2017

\section{ÖZET}

$\mathrm{Bu}$ çalışmada üç farklı çevrede yetiştirilmiş olan altı buğday genotipinin protein içeriği ve fraksiyonlarına, nişasta fraksiyonlarına, nişastanın SSL (sodium stearol-2-laktilat) ve DMG (distilled mono gliserit) bağlama gücüne ve spesifik ekmek hacmine (SLV) çevre ve genotip etkisi araştırılmıştır. Genotip ve çevre incelenen tüm kalite özelliklerini önemli düzeyde etkilemiştir. Ancak protein içeriği ve fraksiyonları genotip ve çevreye bağlı olarak farklılıklar göstermiştir. 
Protein kalite özelliklerinin çoğunda çevreye göre genotip daha etkili olmuştur. Glutenin alt ünitelerinin boyut dağılımları da çevre ve genotip tarafından önemli düzeyde etkilenmiştir. Un protein kapsamı arttıkça monomeric proteinlerin boyutlarının da artma eğilimi gösterirken glutenin içeriğinin azaldığg gözlenmiştir. Un protein içeriği, gliadin ve hamur yapım özellikleri ile yüksek derecede ilişkili olmuştur. Çevre, hem toplam protein hem de ekmek yapım kalitesini belirleyen protein fraksiyonları miktarı üzerine etkili olmuştur.

Anahtar Kelimeler: Buğday genotipleri; Ekmek hacmi; Elektroforez; Moleküler ağırlık; Protein; Nişasta

(C) Ankara Üniversitesi Ziraat Fakültesi

\section{Introduction}

Wheat (Triticum aestivum L.) is an important and most widely cultivated crop in the world, providing $20 \%$ of all calories consumed globally. The primary objective of wheat breeders is to develop varieties with improved agronomic and technological properties, as well as increased amounts of beneficial nutrients and fewer amounts of anti-nutritional factors (Welch 2005). Knowing the biochemical characteristics responsible for the end-use quality features of wheat grains could have major impacts on wheat breeding programs and would lead to develop breeds with overall grain quality like handling, milling, and baking. Wheat flour protein composition or molecular size distribution and solubility have been reported as important variables influencing the processing quality of wheat (Graybosch et al 1996). Differences in both protein quantity and quality meaningfully alter flour quality and bread making. Environmental conditions can induce changes in the secondary, tertiary, or quaternary structure of proteins and thereby affect its structural and functional properties (Kim et al 2000). Protein characteristics in terms of its quantity and quality are the major determinants of the end use quality of wheat flour. The measurable expression of the crude protein in wheat flour is connected with the total organic nitrogen, while protein quality relate precisely to physiochemical features of the gluten constituent at the molecular level (Johansson et al 2003). Following the sequential Osborne extraction procedure, albumins and globulins of wheat endosperm represent 20\% to $25 \%$ of total grain proteins (Merlino et al 2009). Nutritionally, albumins and globulins (non-glutens) have an exceptional amino acid balance (Žilić et al 2011). Further, the same authors reported that numerous of these proteins are enzymes involved in the metabolic activity. Triboi et al (2000) reported that proportions of gliadins in flour increased at higher protein content and lower proportions of glutenin. Glutenin and gliadin are the main constituents of the storage protein in wheat grains and they make a significant influence on the dough rheology and baking features (Panozzo \& Eagles 2000). Differences in both protein content and composition meaningfully alter the bread quality (Panozzo \& Eagles 2000). However, grain protein content and composition depends principally on wheat genotype, but it is also considerably affected by environmental conditions and the interaction between genotype and environment (Zhu \& Khan 2001). Zhang et al (2007) reported that genotype, the environment, and the interaction of these factors expressively affected greatest number of the quality characters and a number of protein fractions. Genotype primarily determined the amount of the protein fractions and bread making factors, whereas the environment was the most significant source of difference in the noodle quality parameters. Further the same authors stated that higher bread scoress with $\mathrm{r}=0.70(\mathrm{P}<0.001)$ and $\mathrm{r}=-0.74(\mathrm{P}<0.001)$ were achieved when using flours with higher quantity of glutenin and lower ratio of gliadin. Though, protein content and composition have a moderate unwanted influence on sensory quality of final products. Consequently, when breeding cultivars with enhanced bread making quality both allelic variation and quantity of storage protein fractions should be considered. A comprehensive understanding of the variability in protein content and composition among newly developed wheat 
inbred lines could assist our continuing efforts to enhance both quantity and quality of wheat proteins and could thus motivate better selection of excellent wheat varieties. Therefore, this study was carried out to examine the effect of genotype and growing environment on protein quality attributes of newly developed wheat genotypes grown in three different environments (Madani, Hudeiba and Dongola) in the Sudan.

\section{Material and Methods}

\subsection{Materials}

Six genotypes of bread wheat (Triticum aestivum L.) (G1, RGO/SERI/TRAP//Bow; G2, KAU2*CHEN// BCN.CMB; G3, PYT\#23 (DWR39xCONDOR "S") 14PXT; G4, TEVEE "S"/SHUHA "S"; G5, CONDOR "S"/14PYT//DWR39; G6; IHSGE\#20) were grown in three different environments. The three environments are; 1, Hudeiba Research Station Farm, longitude $33^{\circ}$ $92^{`} \mathrm{E}$, latitude $17^{\circ} 56^{\prime} \mathrm{N}$ and, with annual temperature of $29.7^{\circ} \mathrm{C}$, rainfall of $117 \mathrm{~mm}$ and relative humidity of $37 \%$; 2, Wad Medani Research Station Farm, longitude $33^{\circ} 29^{\circ} \mathrm{E}$, latitude $14^{\circ} 24^{\prime} \mathrm{N}$ and, with annual temperature of $28.3^{\circ} \mathrm{C}$, rainfall of $362 \mathrm{~mm}$ and relative humidity of $42 \%$; 3 , Dongola, North Sudan, latitude $19^{\circ} 10^{\prime} \mathrm{N}$ and longitude $30^{\circ} 29^{\prime} \mathrm{E}$ and, with annual temperature of $27.6^{\circ} \mathrm{C}$, rainfall of $21 \mathrm{~mm}$ and relative humidity of $35 \%$.

The genotypes were developed through extensive wheat breeding programs at the Agricultural Research Corporation (ARC), Gazira, Sudan. Sodium stearoyl-2-lactylate, distilled mono glyceride, petroleum ether, dithiothreitol, and dimethyl sulfoxide were obtained from SigmaAldrich Co., St. Louis, USA. Unless otherwise stated all the reagents used in the current study were of analytical grade. Three independent replicates of each sample were used for the analysis.

\subsection{Protein content and fractionation}

The protein content was determined according to AOAC (2000). The protein fractions were extracted according to their solubility using the method of Landry \& Moureaux (1970).
2.3. Binding strength of sodium stearoyl-2-lactylate (SSL) and distilled mono glyceride (DMG) to starch

Two-tenths of SSL or DMG was suspended in $100 \mathrm{~mL}$ distilled water at $54{ }^{\circ} \mathrm{C}$ in $400 \mathrm{~mL}$ beaker. About 20 $\mathrm{g}$ of starch were added to the suspension and mixed. The suspension was placed in a preheated oven at $100^{\circ} \mathrm{C}$ for 25 minutes. The mixture was occasionally shaken without stirring. After $25 \mathrm{~min}$, the mixture was taken out and immediately frozen and then freeze dried. The dried sample was then powdered using a laboratory mill and stored at $4{ }^{\circ} \mathrm{C}$. About $10 \mathrm{~g}$ of the freeze-dried starch-surfactant was weighed and extracted in a Gold Fish Apparatus using petroleum ether for $12 \mathrm{~h}$. Petroleum ether was evaporated over boiling water bath, the extracted surfactant was redissolved in $50 \mathrm{~mL}$ of SSL or DMG solvent and transferred quantitatively to a volumetric flask and the volume was completed to $100 \mathrm{~mL}$. A standard surfactant solution was prepared by dissolving $0.20 \mathrm{~g}$ of surfactant in exactly $100 \mathrm{~mL}$ of the corresponding surfactant solvent. The binding strength of SSL and DMG to different starches was measured using gas chromatography-mass spectrophotometry (GC-MS, Shimadzu GC 17A, QP-5000, Japan).

\subsection{Baking test}

The baking test was carried out following the procedure defined previously (Badi et al 1978).

\subsection{Starch and gluten fractionation}

Wheat flour starch and gluten were separated by dough-washing method (Wolf 1964).

\subsection{Molecular weight characterization}

The molecular weight characterization was carried out using microchip capillary electrophoresis according to method of Uthayakumaran et al (2006).

\subsection{Statistical analysis}

The data of three independent experiments were examined by ANOVA and Duncan's multiple range test (DMRT). Correlation coefficients among all quality traits were evaluated based on the means of all genotypes in the individual environment using Stat View software. Significance was accepted at $\mathrm{P}<0.05, \mathrm{P}<0.01$, and $\mathrm{P}<0.001$. 


\section{Results and Discussion}

\subsection{Protein content and fractions}

As shown in Table 1, the protein content (PRC) varied between genotypes and location (Madani, Hudeiba, and Dongola). Among the lines grown in Madani, Hudeiba and Dongola, lines G4, G2, and G2, exhibited 13.4, 14.06, and 13.87\% PRC, respectively. Among the locations, Dongola gave higher average PRC value (13.38\%) followed by Hudeiba $(13.10 \%)$ and Madani (11.82\%). The PRC of G2 grown at Hudieba is comparable to that of the Canadian cultivar. The variation in PRC among location could be attributed to changes in environmental conditions, cultivation practices as well as genotypes. The results revealed that the PRC of wheat has been connected more with environmental factors, such as rainfall, temperature, soil fertility, and fertilizer application practices, than genetic makeup. Bouacha et al (2014) reported that the grains PRC depend on agronomical practices, genotypes, soil nitrogen content, heat and drought stresses. The environment was the most powerful variable, though some authors reported that genotype and genotype-by-environment had superior influence on flour protein than the environment (Grausgruber et al 2000). The mean values of the protein fractions of the genotypes grown at the three locations are presented in Table 2. The average value of globulins for each of the

Table 1- Protein content (g $\left.100 \mathrm{~g}^{-1}\right)$ and fractions (\% of total protein), starch and gluten fractions (g), SSL and DMG ( $\left.\mathrm{mg} \mathrm{g}^{-1}\right)$ and specific loaf volume $\left(\mathrm{cm}^{3} \mathrm{~g}^{-1}\right)$ of six local wheat genotypes grown at three different locations and Canadian wheat flour

\begin{tabular}{|c|c|c|c|c|c|c|c|c|c|c|c|c|c|}
\hline Location & Lines & $P R C$ & $G L B$ & $A L B$ & $G L I$ & $G L T$ & $I N S P$ & STF & GTF & $\begin{array}{l}\text { SSL } \\
\text { binding }\end{array}$ & $\begin{array}{l}D M G \\
\text { binding }\end{array}$ & $S L V$ & $\begin{array}{l}\text { GLT/ } \\
G L I \\
\end{array}$ \\
\hline \multirow[t]{6}{*}{ Madani } & G1 & $11.15^{\mathrm{b}^{*}}$ & $26.32^{\mathrm{a}}$ & $12.39^{\mathrm{c}}$ & $39.85^{\mathrm{c}}$ & $22.26^{\mathrm{a}}$ & $0.49^{\mathrm{a}}$ & $49.38^{c}$ & $17.00^{c}$ & $178.62^{b}$ & $200.00^{\mathrm{a}}$ & $2.40^{\mathrm{c}}$ & 0.56 \\
\hline & G2 & $10.94^{\mathrm{c}}$ & $21.33^{b}$ & $14.00^{\mathrm{b}}$ & $40.63^{\mathrm{cb}}$ & $21.97^{\mathrm{a}}$ & $0.49^{\mathrm{a}}$ & $55.18^{\mathrm{b}}$ & $19.86^{\mathrm{a}}$ & $166.95^{\mathrm{c}}$ & $187.12^{\mathrm{b}}$ & $2.92^{\mathrm{b}}$ & 0.54 \\
\hline & G3 & $10.36^{\mathrm{c}}$ & $21.61^{\mathrm{b}}$ & $15.89^{\mathrm{a}}$ & $41.38^{\mathrm{b}}$ & $22.94^{\mathrm{a}}$ & $0.46^{\mathrm{b}}$ & $54.97^{\mathrm{b}}$ & $16.86^{\mathrm{c}}$ & $108.97^{\mathrm{d}}$ & $200.00^{\mathrm{a}}$ & $2.91^{\mathrm{b}}$ & 0.55 \\
\hline & G4 & $13.40^{\mathrm{a}}$ & $19.57^{b}$ & $9.36^{d}$ & $50.58^{\mathrm{a}}$ & $20.74^{b}$ & $0.42^{\mathrm{c}}$ & $43.31^{\mathrm{d}}$ & $18.83^{\mathrm{b}}$ & $200.00^{\mathrm{a}}$ & $160.90^{c}$ & $3.44^{\mathrm{a}}$ & 0.41 \\
\hline & G5 & $12.25^{\mathrm{b}}$ & $21.40^{\mathrm{b}}$ & $12.99^{\mathrm{c}}$ & $49.93^{\mathrm{a}}$ & $17.91^{\mathrm{c}}$ & $0.42^{\mathrm{c}}$ & $60.15^{\mathrm{a}}$ & $16.05^{\mathrm{c}}$ & $200.00^{\mathrm{a}}$ & $200.00^{\mathrm{a}}$ & $2.92^{b}$ & 0.36 \\
\hline & G6 & $12.81^{\mathrm{b}}$ & $18.59^{\mathrm{c}}$ & $14.46^{\mathrm{b}}$ & $48.95^{\mathrm{a}}$ & $19.91^{\mathrm{b}}$ & $0.42^{\mathrm{c}}$ & $55.62^{\mathrm{ab}}$ & $19.24^{\mathrm{ab}}$ & $200.00^{\mathrm{a}}$ & $200.00^{\mathrm{a}}$ & $3.35^{\mathrm{a}}$ & 0.41 \\
\hline \multicolumn{2}{|c|}{ Location Mean } & $11.82^{\mathrm{C}}$ & $21.47^{\mathrm{B}}$ & $13.18^{\mathrm{A}}$ & $45.22^{\mathrm{B}}$ & $20.95^{\mathrm{A}}$ & $0.45^{\mathrm{A}}$ & $53.10^{\mathrm{A}}$ & $17.97^{\mathrm{B}}$ & $175.75^{\mathrm{C}}$ & $191.30^{\mathrm{C}}$ & $2.99^{\mathrm{C}}$ & 0.46 \\
\hline \multirow[t]{6}{*}{ Hudeiba } & G1 & $13.60^{\mathrm{a}}$ & $25.48^{\mathrm{c}}$ & $9.28^{d}$ & $42.32^{\mathrm{d}}$ & $21.23^{\mathrm{a}}$ & $0.40^{\mathrm{c}}$ & $50.60^{c}$ & $16.23^{\mathrm{c}}$ & $200.00^{\mathrm{a}}$ & $200.00^{\mathrm{a}}$ & $2.45^{\mathrm{b}}$ & 0.50 \\
\hline & G2 & $14.06^{\mathrm{a}}$ & 22.02 & $12.41^{\mathrm{b}}$ & $47.60^{\mathrm{b}}$ & $18.89^{\mathrm{d}}$ & $0.42^{\mathrm{c}}$ & $37.21^{\mathrm{e}}$ & $19.23^{\mathrm{a}}$ & $200.00^{\mathrm{a}}$ & $200.00^{\mathrm{a}}$ & $2.56^{\mathrm{b}}$ & 0.40 \\
\hline & G3 & $12.63^{\mathrm{b}}$ & $31.24^{\mathrm{a}}$ & $11.46^{\mathrm{c}}$ & $37.81^{\mathrm{e}}$ & $20.36^{\mathrm{b}}$ & $0.45^{\mathrm{b}}$ & $43.30^{\mathrm{d}}$ & $11.89^{\mathrm{e}}$ & $200.00^{\mathrm{a}}$ & $200.00^{\mathrm{a}}$ & $2.53^{b}$ & 0.54 \\
\hline & G4 & $13.13^{\mathrm{a}}$ & $25.42^{\mathrm{c}}$ & $12.66^{\mathrm{b}}$ & $45.16^{\mathrm{c}}$ & $19.44^{\mathrm{c}}$ & 0.40 & $55.84^{\mathrm{a}}$ & $17.85^{\mathrm{b}}$ & $200.00^{\mathrm{a}}$ & $189.00^{c}$ & $2.91^{\mathrm{a}}$ & 0.43 \\
\hline & G5 & $12.63^{b}$ & $26.51^{\mathrm{b}}$ & $12.71^{\mathrm{b}}$ & $43.25^{\mathrm{d}}$ & $19.37^{\mathrm{c}}$ & $0.48^{\mathrm{a}}$ & $34.62^{\mathrm{f}}$ & $13.85^{\mathrm{d}}$ & $198.30^{b}$ & $200.00^{\mathrm{a}}$ & $2.91^{\mathrm{a}}$ & 0.45 \\
\hline & G6 & $12.55^{\mathrm{b}}$ & $20.28^{d}$ & $13.32^{\mathrm{a}}$ & $50.02^{\mathrm{a}}$ & $18.57^{\mathrm{d}}$ & $0.41^{\mathrm{c}}$ & $53.00^{\mathrm{b}}$ & $18.00^{\mathrm{ab}}$ & $200.00^{\mathrm{a}}$ & $192.58^{b}$ & $3.30^{\mathrm{a}}$ & 0.37 \\
\hline \multicolumn{2}{|c|}{ Location Mean } & $13.10^{\mathrm{B}}$ & $25.15^{\mathrm{A}}$ & $11.97^{\mathrm{B}}$ & $44.36^{\mathrm{C}}$ & $19.64^{\mathrm{B}}$ & $0.42^{\mathrm{A}}$ & $45.76^{\mathrm{B}}$ & $16.17^{\mathrm{C}}$ & $199.71^{\mathrm{A}}$ & $196.93^{\mathrm{A}}$ & $2.78^{\mathrm{C}}$ & 0.44 \\
\hline \multirow[t]{6}{*}{ Dongla } & G1 & $12.36^{\mathrm{b}}$ & $30.48^{\mathrm{a}}$ & $11.56^{\mathrm{c}}$ & $37.19^{\mathrm{e}}$ & $20.74^{b}$ & $0.49^{\mathrm{a}}$ & $38.75^{\mathrm{c}}$ & $12.43^{\mathrm{c}}$ & $200.00^{\mathrm{a}}$ & $191.85^{\mathrm{a}}$ & $2.79^{b}$ & 0.56 \\
\hline & G2 & $13.87^{\mathrm{a}}$ & $25.04^{b}$ & $12.74^{\mathrm{b}}$ & $42.92^{\mathrm{d}}$ & $21.39^{\mathrm{a}}$ & $0.49^{\mathrm{a}}$ & $30.29^{d}$ & $14.43^{\mathrm{b}}$ & $200.00^{\mathrm{a}}$ & $188.00^{\mathrm{b}}$ & $2.77^{\mathrm{b}}$ & 0.50 \\
\hline & G3 & $13.55^{\mathrm{a}}$ & $23.13^{c}$ & $10.74^{\mathrm{c}}$ & $45.41^{\mathrm{c}}$ & $21.46^{\mathrm{a}}$ & $0.41^{\mathrm{b}}$ & $44.34^{\mathrm{a}}$ & $19.13^{\mathrm{a}}$ & $198.60^{b}$ & $178.60^{\mathrm{d}}$ & $2.81^{\mathrm{b}}$ & 0.47 \\
\hline & G4 & $13.76^{\mathrm{a}}$ & $25.01^{\mathrm{b}}$ & $6.09^{\mathrm{d}}$ & $51.39^{\mathrm{a}}$ & $19.46^{\mathrm{c}}$ & $0.41^{\mathrm{b}}$ & $41.89^{b}$ & $18.60^{\mathrm{a}}$ & $200.00^{\mathrm{a}}$ & $180.30^{\mathrm{c}}$ & $3.51^{\mathrm{a}}$ & 0.38 \\
\hline & G5 & $13.68^{\mathrm{a}}$ & $21.93^{\mathrm{d}}$ & $14.69^{\mathrm{a}}$ & $42.39^{\mathrm{d}}$ & $18.37^{\mathrm{d}}$ & $0.41^{\mathrm{b}}$ & $44.93^{\mathrm{a}}$ & $18.23^{\mathrm{a}}$ & $195.40^{\mathrm{c}}$ & $106.10^{f}$ & $2.83^{\mathrm{b}}$ & 0.43 \\
\hline & G6 & $13.11^{\mathrm{a}}$ & $19.37^{\mathrm{e}}$ & $12.05^{\mathrm{b}}$ & $46.86^{\mathrm{b}}$ & $19.51^{\mathrm{c}}$ & $0.41^{\mathrm{b}}$ & $45.16^{\mathrm{a}}$ & $19.30^{\mathrm{a}}$ & $195.70^{c}$ & $127.60^{\mathrm{e}}$ & $3.54^{\mathrm{a}}$ & 0.42 \\
\hline \multicolumn{2}{|c|}{ Location Mean } & $13.38^{\mathrm{B}}$ & $24.16^{\mathrm{A}}$ & $11.31^{\mathrm{B}}$ & $44.36^{\mathrm{C}}$ & $20.15^{\mathrm{A}}$ & $0.43^{\mathrm{A}}$ & $40.89^{\mathrm{D}}$ & $17.02^{\mathrm{B}}$ & $198.28^{\mathrm{B}}$ & $162.07^{\mathrm{D}}$ & $3.04^{\mathrm{B}}$ & 0.45 \\
\hline \multicolumn{2}{|c|}{ Canadian wheat } & $14.60^{\mathrm{A}}$ & $21.82^{\mathrm{B}}$ & $13.75^{\mathrm{A}}$ & $46.94^{\mathrm{A}}$ & $18.37^{\mathrm{B}}$ & $0.43^{\mathrm{B}}$ & $43.61^{\mathrm{C}}$ & $18.5^{\mathrm{A}}$ & $166.40^{\mathrm{D}}$ & $195.24^{\mathrm{B}}$ & $4.00^{\mathrm{A}}$ & 0.39 \\
\hline
\end{tabular}


three locations genotypes ranged from 18.59 to $26.32 \%$ for Madani location, 20.28 to $31.24 \%$ for Hudeiba, and 19.37 to $30.48 \%$ for Dongola, while the Canadian wheat exhibited $21.82 \%$. Albumin ranged from 9.36 to $15.89 \%$ for Madani and from 9.28 to $13.32 \%$ for Hudeiba and from 6.09 to
$16.69 \%$ for Dongola while $13.75 \%$ was reported for the Canadian. Gliadin is a dominant fraction of all genotypes grown in all locations. Among genotypes grown in Madani, the highest gliadin value (50.58\%) was recorded in G5 compared to $39.85 \%$ for G1. A mean value of $50.02 \%$ gliadin as a highest value in

Table 2- Correlation coefficient among the protein quality attributes of wheat genotypes grown at three different locations

\begin{tabular}{|c|c|c|c|c|c|c|c|c|c|c|}
\hline & $P R C$ & $G L B$ & $A L B$ & $G L I$ & $G L T$ & INSP & $G T F$ & STF & $S S L$ & $D M G$ \\
\hline \multicolumn{11}{|c|}{ Wad Madani } \\
\hline GLB & -0.58 & & & & & & & & & \\
\hline ALB & -0.68 & 0.01 & & & & & & & & \\
\hline GLI & $0.91 * *$ & -0.70 & -0.47 & & & & & & & \\
\hline GLT & -0.67 & 0.41 & 0.25 & $-0.82 *$ & & & & & & \\
\hline INSP & $-0.81 *$ & 0.73 & 0.29 & $-0.97 * * *$ & 0.76 & & & & & \\
\hline GTF & 0.26 & -0.50 & -0.12 & 0.03 & 0.20 & 0.07 & & & & \\
\hline STF & -0.34 & -0.09 & 0.75 & -0.04 & -0.39 & -0.04 & -0.29 & & & \\
\hline SSL & $0.84 *$ & -0.24 & -0.65 & 0.68 & -0.74 & -0.50 & 0.22 & -0.15 & & \\
\hline DMG & -0.54 & 0.36 & 0.79 & -0.38 & -0.03 & 0.24 & -0.48 & 0.77 & -0.30 & \\
\hline SLV & 0.73 & $-0.96 * * *$ & -0.25 & 0.76 & -0.37 & -0.76 & 0.53 & -0.19 & 0.34 & -0.57 \\
\hline \multicolumn{11}{|c|}{ Hudeiba } \\
\hline GLB & -0.31 & & & & & & & & & \\
\hline ALB & -0.39 & -0.39 & & & & & & & & \\
\hline GLI & 0.20 & $-0.98 * * *$ & 0.57 & & & & & & & \\
\hline GLT & 0.15 & 0.64 & $-0.94 * *$ & -0.77 & & & & & & \\
\hline INSP & -0.48 & 0.49 & 0.24 & -0.43 & -0.08 & & & & & \\
\hline GTF & 0.59 & $-0.89 *$ & 0.26 & $0.87 *$ & -0.50 & -0.72 & & & & \\
\hline STF & -0.11 & -0.21 & -0.11 & 0.21 & 0.13 & -0.80 & 0.33 & & & \\
\hline SSL & 0.37 & -0.17 & -0.25 & 0.13 & 0.14 & $-0.82 *$ & 0.41 & 0.63 & & \\
\hline DMG & 0.25 & 0.36 & -0.49 & -0.49 & 0.42 & 0.53 & -0.47 & -0.77 & -0.31 & \\
\hline SLV & -0.60 & -0.53 & 0.77 & 0.65 & -0.73 & -0.02 & 0.28 & 0.32 & -0.20 & -0.68 \\
\hline \multicolumn{11}{|c|}{ Dongola } \\
\hline GLB & -0.49 & & & & & & & & & \\
\hline ALB & -0.10 & -0.22 & & & & & & & & \\
\hline GLI & 0.60 & -0.55 & -0.67 & & & & & & & \\
\hline GLT & -0.11 & 0.43 & -0.10 & -0.28 & & & & & & \\
\hline INSP & -0.37 & 0.743 & 0.23 & -0.70 & 0.57 & & & & & \\
\hline GTF & 0.50 & $-0.85^{*}$ & -0.21 & 0.78 & -0.44 & $-0.97 * * *$ & & & & \\
\hline STF & -0.12 & -0.51 & -0.07 & 0.32 & -0.58 & $-0.86^{*}$ & 0.74 & & & \\
\hline SSL & -0.06 & 0.79 & -0.57 & -0.06 & 0.68 & 0.61 & -0.58 & -0.67 & & \\
\hline DMG & -0.15 & 0.74 & -0.53 & -0.09 & $0.81 *$ & 0.60 & -0.55 & -0.62 & $0.97 * * *$ & \\
\hline SLV & 0.06 & -0.44 & -0.58 & 0.77 & -0.45 & -0.54 & 0.55 & 0.41 & -0.21 & -0.22 \\
\hline
\end{tabular}

PRC, protein content; GLB, globulin; ALB, albumin; GLI, gliadin; GLT, glutenin; INSP, insoluble protein; GTF, gluten fraction; STF, starch fraction; SSL, sodium stearoyl lactylate; DMG, distilled mono glyceride; SLV, specific loaf volume; ${ }^{*}, \mathrm{P}<0.05 ;{ }^{*} \mathrm{P}<0.01 ;{ }^{* * *} \mathrm{P}<0.001$ 
Hudeiba was observed for G6 compared to $37.81 \%$ as the lowest observed for G3. For genotypes grown in Dongola, G4 had higher gliadin value (51.39 \%) where G1 scored the lowest (37.19\%). Canadian wheat recorded $46.95 \%$ of gliadin. The results showed that some genotypes among locations have higher gliadin content compared to the other gluten fraction. Generally, gliadins have been reported for its contribution to dough viscosity (Uthayakumaran et al 1999). Glutenin fraction of G3 (22.94\%) of Madani was the highest relative to lowest exhibited by G5 (17.91\%), while at Hudeiba the values for G2 and G6 were $21.23 \%$ and $18.57 \%$, respectively. Dongola data showed $21.46 \%$ for G3 and $18.37 \%$ for G5 as the highest and lowest values, respectively. Canadian wheat exhibited $18.37 \%$ of glutenin. The glutenin content of the investigated genotypes was superior to that of the Canadian, which indicated that the dough elasticity will be improved because glutenins contribute to dough elasticity (Uthayakumaran et al 1999).

The insoluble protein fraction for all genotypes that grown in all locations range from 0.40 to $0.49 \%$ while that of Canadian wheat was $0.43 \%$. Regarding the sites, the mean value of globulin of genotypes grown in Hudeiba $(25.15 \%)$ was the highest followed by Dongola (24.16\%) and Madani $(21.47 \%)$ while that of albumin Madani recorded higher value (13.18\%) followed by Hudeiba (11.97\%) and Dongola (11.31\%). The average value of gliadin and glutenin fractions was greater in Madani and were found to be 45.22 and $20.95 \%$, respectively, followed by Dongola which gave 44.36 and $20.15 \%$, respectively, and Hudeiba scored 44.36 and $19.64 \%$, respectively. The mean value of insoluble protein of genotypes was found to be higher for lines grown in Madani $(0.45 \%)$ followed by those grown in Dongola $(0.43 \%)$ and Hudeiba $(0.42 \%)$ while Canadian cultivar showed $0.43 \%$. Zhu \& Khan (2001) reported that the environment not only influenced total flour protein content but it also affected the amounts of various protein fractions and the molecular size distributions of glutenin subunits. Panozzo \& Eagles (2000) reported that the proportion of glutenin in flour protein was extremely dependent on cultivar, whereas, the effect of environmental difference was greater than cultivar variation for gliadin, though cultivar selection was still necessary. Environmental variation influence was higher than cultivar variation for the dough rheological properties. Further, Panozzo \& Eagles (2000) reported that throughout the environments, the amount of gliadin improved with increasing the flour protein content, while the share of glutenin declined. Zhang et al (2007) declared that genotype, environment, and their interaction meaningfully affected most of the wheat quality characters and the quantity of protein fractions. Our study revealed that genotype mainly determined the quantity of gluten protein fractions while the environment was the greatest cause of differences in other quality factors. Johansson et al (2003) reported that cultivar and environmental inspirations elevated the discrepancy in protein content and they also increased the differences in most of the examined protein constituents.

\subsection{Starch and gluten fractions}

Genotypes, G5 (60.15 g), G4 (55.84 g) and G6 (54.16 g) grown in Madani, Hudeiba and Dongola, respectively gave significantly $(\mathrm{P}<0.01)$ higher values of starch fraction (Table 1). Regarding gluten fraction, G2 (19.86 g), G2 (19.23 g) and G6 (19.30 g) for the locations, respectively gave significantly $(\mathrm{P}<0.01)$ higher values. Genotypes grown in Madani gave significantly $(\mathrm{P}<0.01)$ higher average value of starch fraction $(53.10 \mathrm{~g})$ followed by Hudeiba (45.76 g) and Dongola (40.89 g) while Canadian cultivar had a value of $43.61 \mathrm{~g}$. The mean value of gluten fraction of all genotypes for each location was differed from each other and slightly lower than that of the Canadian cultivar. Significant variations in starch and gluten fractions were observed $(\mathrm{P}<0.01)$ among genotypes. However, among locations, the starch fraction was significantly varied but gluten fraction did not vary significantly indicating that genotype and location had have affected starch and gluten yield. The results obtained are in accordance with those of Wilson et al (2008) who stated that the environment impact on wheat properties seemed 
to have a significant effect on bread baking quality and various starch properties than genetic control. In addition, our results are close to that obtained by Sayaslan et al (2006) who found a range of $54.50-63.40 \%$ for starch yield and $3.70-18.20 \%$ for gluten yield. The excess gluten recovery of wheat flour protein could be attributed to the fact that the isolated gluten contains lipid, carbohydrate and other minor components in addition to protein (Van Der Borght et al 2005). Significant differences in isolated starch and gluten are of great importance for the starch/gluten industry and they could thus be used for selection of wheat cultivars with appropriate characteristics to meet specific requirements.

\subsection{Binding ability of sodium stearoyl-2-lactylate (SSL) and distilled mono glyceride (DMG)}

The binding strength of SSL and DMG to different starches was measured using gas chromatographymass spectrophotometry and the results are presented in Table 1. The binding strength of SSL of G4, G5 and G6 (200.00 $\mathrm{mg} \mathrm{g}^{-1}$ ) significantly $(\mathrm{P}<0.01)$ varied among genotypes grown in Madani and no significant variation in SSL binding ability of genotypes grown in Hudeiba which exhibited a range of 198.30 to $200.00 \mathrm{mg} \mathrm{g}^{-1}$. For genotype grown in Dongola G1-G4 showed significantly $(\mathrm{P}<0.01)$ higher values compared to other genotypes G5 and G6. Among locations, the average value of genotypes grown in Hudeiba gave significantly higher SSL binding ability followed by Dongola while those grown in Madani gave the least mean value but still greater than that obtained from Canadian cultivar $\left(166.40 \mathrm{mg} \mathrm{g}^{-1}\right)$. DMG binding ability of the starch of genotypes grown in Madani varied between genotypes with G1, G3, G5 and G6 showed considerably $(\mathrm{P}<0.01)$ higher value $(200.00$ $\mathrm{mg} \mathrm{g}^{-1}$ ) while those grown in Hudeiba, G1, G2, G3, and G5 recorded significantly $(\mathrm{P}<0.01)$ higher values. However, for genotypes grown in Dongola only G1 scored considerably $(\mathrm{P}<0.01)$ higher value $\left(191.85 \mathrm{mg} \mathrm{g}^{-1}\right)$. Among locations, the average value of DMG binding ability of the starch of genotypes grown in Hudeiba was significantly $(\mathrm{P}<0.01)$ higher than those grown in Madani and Dongola as well as that of Canadian cultivar. It has been reported that sodium stearoyl-2-lactylate (SSL) is an anionic oil-in-water emulsifier that is used to enhance the quality of bread. When added to the dough, SSL could improve mixing tolerance, gas retention, and dough resistance and it is thus known as dough strengther (Ribotta et al 2010). Nonionic emulsifiers such as distilled mono glyceride (DMG) play a major role in bread volume and crumb texture (Gray \& Bemiller 2003). The results revealed that the effect of surfactants differed with the type of starch. High significant differences for genotypes and locations were found to affect the starch binding ability. SSL and distilled monodiglyceride (as dough strengtheners) their binding capacity of the newly developed lines is comparable to those of Canadian cultivar which indicated that the end-use of such genotypes will be highly improved.

\subsection{Specific loaf volume}

The mean specific loaf volume (SLV) of the newly developed genotypes is shown in Table 1. Among genotypes grown in Madani, genotype G4 scored significantly higher value of SLV $\left(3.44 \mathrm{~cm}^{3} \mathrm{~g}^{-1}\right)$ than the other genotypes while G6 gave higher value $\left(3.30 \mathrm{~cm}^{3} \mathrm{~g}^{-1}\right)$ and among those grown in Hudeiba and those grown in Dongola $\left(3.54 \mathrm{~cm}^{3} \mathrm{~g}^{-1}\right)$. Among the locations, the average SLV of genotypes grown in Dongola gave higher value $\left(3.05 \mathrm{~cm}^{3} \mathrm{~g}^{-1}\right)$ than those grown in Madani and Hudeiba but lower than that of the Canadian cultivar. It has been reported that the protein content and GLT/GLI ratio have different influences on dough and bread quality parameters. Rises in the protein content at constant GLT/GLI ratio improved extensibility, mixograph peak resistance, maximum resistance to extension, mixing time, and loaf volume. Increases in the GLT/ GLI ratio at constant protein content increased mixing time, mixograph peak resistance, maximum resistance to extension and loaf volume. Rises in GLT/GLI ratio decreased resistance breakdown and extensibility (Huang \& Khan 1997). However, in the present study a negative correlation $(\mathrm{r}=-0.64$, -0.71 and -0.74 for the genotypes grown in Madani, Hudieba and Dongola, respectively) was observed 
between GLT/GLI ratio and the loaf volume which indicated that as GLT decreases the loaf volume increases. Although there was an improvement in most of the quality attributes such as glutenin and insoluble (aggregated) gluten fraction, that responsible for the improvement of the baking quality of the flour of the investigated genotypes compared to that of Canadian, but the loaf volume of the investigated genotypes was found to be lower than that of the Canadian cultivar. The variation in a specific loaf volume of the investigated genotypes and Canadian may be due to the differences in genetic, as well as environmental conditions among the locations, the genotype, and it's interaction with the environment. In addition, differences in the chemical nature of gluten and gluten fractions between the investigated genotypes and the Canadian cultivar may exist. Similar results have been reported by Wilson et al (2008) who reported that loaf volume was correlated with protein quantity and quality. The dough forming ability of wheat flour during fermentation is the main determinants of its baking properties. Therefore, dough strength contributes to the quality of both flour and bread.

\subsection{Correlation among quality attributes}

Correlation analysis of wheat flour end-use quality standards is one of the striking approaches that can yield sufficient evidence of association of qualitative characteristics and their interaction effects that provide a proper evaluation of the overall quality of wheat flour. Table 2 shows the correlation between the protein content, protein factions, starch and gluten fractions, and sodium stearoyl lactylate (SSL) and distilled monodiglyceride (DMG) binding properties of the six wheat genotypes grown in different locations in Sudan (Madani, Hudeiba, and Dongola). The results showed that the correlations were varied between attributes (positive, negative, weak) of genotypes. The protein content (PRC) was considerably $(\mathrm{P}<0.01)$ and positively associated $(\mathrm{r}=0.91)$ with gliadin (GLI) and significantly $(\mathrm{P}<0.05)$ correlated with SSL $(\mathrm{r}=0.84)$ but negatively interrelated $(\mathrm{P}<0.05, \quad \mathrm{r}=-0.81)$ with insoluble protein (INSP) for genotypes grown in
Madani, while the PRC of those grown in Hudeiba and Dongola showed weak correlation (either + ve or -ve) with the quality attributes. Similarly, previous reports showed a high correlation between wheat flour protein and gliadin fraction (Saint Pierre et al 2008). In addition, Johansson et al (2003) reported a positive correlation between protein concentration and the total quantities of glutenins, gliadins, and mono- and polymeric proteins. They also reported that the correlation between the quantity of gliadins and sodium dodecyl suphate (SDS)-soluble monoand polymeric proteins were frequently greater than the association between glutenins and the SDS-insoluble mono- and polymeric proteins. The globulin (GLB) content of genotypes grown in Madani was significantly $(\mathrm{P}<0.001)$ and negatively interrelated $(\mathrm{r}=-0.96)$ with specific loaf volume (SLV) while for those grown in Hudieba it was significantly $(\mathrm{P}<0.001)$ and negatively interrelated $(\mathrm{r}=-0.98)$ with GLI and considerably $(\mathrm{P}<0.05)$ and negatively correlated $(\mathrm{r}=-0.89)$ with gluten fraction (GTF). For those grown in Dongola, GLB significantly $(\mathrm{P}<0.05)$ and negatively correlated $(\mathrm{r}=-0.85)$ with gluten fraction (GTF). Similarly, Whitney et al (2014) reported a highly negative association between loaf volume and globulin and albumin fractions. The albumin (ALB) fraction of genotypes grown in Madani and Dongola showed weak correlation (either +ve or -ve) with the quality attributes but for those grown at Hudeiba was significantly $(\mathrm{P}<0.01)$ and negatively correlated $(\mathrm{r}=-0.94)$ with glutenin (GLT). GLI of genotypes grown at Madani was significantly $(\mathrm{P}<0.05)$ and negatively correlated $(\mathrm{r}=-0.82)$ with GLT and INSP $(\mathrm{P}<0.001, \mathrm{r}=-0.97)$ while that of those grown in Hudeiba was significantly $(\mathrm{P}<0.05)$ and positively correlated $(\mathrm{r}=0.87)$ with GTF. However, genotypes grown at Dongola showed a weak correlation (either +ve or -ve) with the quality attributes. A weak correlation (either +ve or -ve) of GLT with the quality characteristics of genotypes grown at Madani and Hudeiba was observed but significantly $(\mathrm{P}<0.05)$ and positively correlated $(\mathrm{r}=0.81)$ with distilled monodiglyceride (DMG) binding property for those grown at Dongola. The INSP of genotype grown at Madani showed weak correlation 
(either + ve or $-v e$ ) with the quality attributes but significantly $(\mathrm{P}<0.05)$ and negatively correlated $(r=-0.82)$ with SSL for those grown at Hudeiba and significantly $(\mathrm{P}<0.001)$ and negatively correlated $(\mathrm{r}=0.97)$ with GTF and STF $(\mathrm{P}<0.05, \mathrm{r}=0.86)$. STF and DMG showed a weak correlation (either + ve or -ve) with the quality attributes for genotypes grown in all location. However, SSL showed only significant $(\mathrm{P}<0.001)$ and positive correlation $(\mathrm{r}=0.97)$ with $\mathrm{DMG}$ for genotypes grown in Dongola.

\subsection{Molecular weight characterization}

Microchip capillary electrophoresis was used to characterize the page pattern of the proteins of the six genotypes (Figure 1). As shown in Figure 1, there were variations in molecular weight of genotypes grown in Madani which ranged from 14.30 to $224.70,13.60$ to $220.90,14.30$ to $223.60,13.90$ to $220.10,13.90$ to 181.20 and 13.80 to $211.70 \mathrm{kDa}$ for genotypes G1, G2, G3, G4, G5 and G6, respectively. For those grown in Hudeiba also showed variations in genotypes molecular weight which ranged from 14.30 to $225.70,14.30$ to $222.70,14.30$ to 217.90 , 14.20 to $219.90,14.00$ to 181.80 and 14.90 to $212.30 \mathrm{kDa}$ for genotypes G1, G2, G3, G4, G5 and G6, respectively. Whereas those grown in Dongola gave a range of 14.20-224.20, 14.20-222.10, 13.80$235.00,14.20-221.80,13.70-183.70$ and $14.30-$ $213.20 \mathrm{kDa}$ for the genotypes, respectively. The Canadian cultivar protein molecular weight ranged from 14.20 to $217.60 \mathrm{kDa}$. The results revealed significant variations among locations and among genotypes in high molecular weight subunits. The highest molecular weight subunit was obtained for genotype grown in Dongola (235 kDa) while the lowest one was obtained for that grown in Madani $(181.20 \mathrm{kDa})$. Among genotypes grown in Madani, the highest molecular weight was scored by G3 and the lowest was for G5. Regarding those genotype grown at Hudeiba, G1 recorded higher molecular weight $(225.70 \mathrm{kDa})$, and G5 recorded the lower one $(181.80 \mathrm{kDa})$. The genotypes grown in Dongola characterized by high molecular weight subunits with a higher one recorded for G3 and lower one recorded for G5. It was observed that G5 at all locations gave a lower value among higher molecular weight subunits. The justification for this variation is not known, but it might be due to the differences in HMW subunits between the genotypes as well as locations. These molecular variances might lead to variations in response to the environment, but which are not observable in other genotypes. Compared to Canadian cultivar, most of the genotypes had higher molecular weight subunits than that of the Canadian. The high molecular weight glutenin subunits (HMW-GS) which has the highest molecular size are shown in the upper part of the measuring range clearly revealed that, the HMW subunits appeared in the range of 100-240 $\mathrm{kDa}$ with Lab-on-a-chip. Well distinguished from the other proteins, above $100 \mathrm{kDa}$. At the middle of the measuring range, the applied procedure provides the patterns of the LMW-GS and gliadin fractions, in the range of 40 and $50 \mathrm{kDa}$, which are entirely overlapping. Below $30 \mathrm{kDa}$ there are mainly albumins and globulins. The results, however, indicate that the effect of the environmental conditions on the protein profile is detectable with Lab-on-a-chip. Other studies confirmed that the environmental conditions such as fertilizer and temperature mainly affect the quantity, composition and/or polymerization of gluten proteins. For example under increased nitrogen fertilizer an increase in gliadin/glutenin and HMWGS/LMW-GS ratios were observed (Dupont et al 2006). Analysis of variance demonstrated an important influence of environmental conditions on molar masses of the polymeric fraction of wheat flours. The six selected local wheat cultivars used in the present study had very diverse allelic compositions of their high molecular weight, these differences in properties presumably arise due to the effects of varying climate, soil type, and agronomic practices on the quantities' variation in gluten protein composition, i.e. relative amounts of gliadin and glutenin proteins and the molecular size distribution of glutenin. Southan \& MacRitchie (1999) reported that wheat proteins molecular weight distribution was known as the primary determinant of physical features of dough. Pevious reports have shown that properties such as stretchy strength are associated with a fraction of polymer having molecular weight 
above a critical value and the molecular weight distribution of this fraction (Southan \& MacRitchie 1999). The proportion of monomeric and polymeric proteins and the molecular weight distribution of the polymeric proteins determine the molecular weight distribution of wheat proteins (Rhazi et al 2014). The molecular weight distribution of the polymeric proteins depends mainly on HMW-GS/ LMW-GS ratio, allelic variation of HMW-GS, and the occurrence of altered gliadins that act as chain terminators (Rhazi et al 2014).
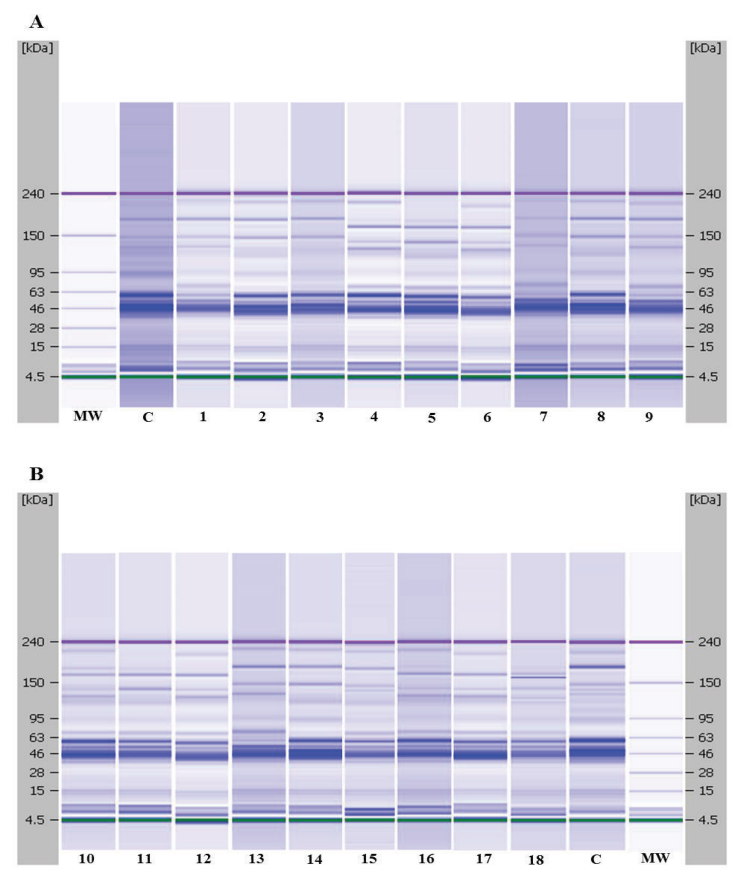

Figure 1 (A, B)- Molecular weight characterization of wheat genotypes proteins by microchip capillary electrophoresis; lane 1-6 (G1-G6, Madani); lane 7-12 (G7-G12, Hudeiba); lane 13-18 (G13-G18, Dongola); MW, molecular marker; C, Canadian wheat (control)

\section{Conclusions}

In conclusion, the results obtained clearly indicate that both the genotype and environment significantly affected the protein and starch quality attributes. Among genotypes grown in Madani and Hudieba, G6 gave the highest loaf volume, SSL, and DMG binding ability and therefore the flour of this genotype is potentially suitable for breadmaking. The remaining genotypes presented little breadmaking characteristics and thus their flours might be used for other bakery products. The low breadmaking quality of such genotypes make alarm for the needs of breeding wheat genotypes with high yield and excellent bread making quality suitable for the environment of the Sudan.

\section{References}

AOAC (2000). Association of Official Analytical Chemists $14^{\text {th }}$ ed. Washington, DC. Official Methods of Analysis

Badi S M, Elfaki H A \& Perten H (1978). Evaluation of Sudanese wheat varieties. Sudan Journal of Food Science and Technology 10: 5-11

Bouacha O D, Nouaigui S \& Rezgui S (2014). Effects of $\mathrm{N}$ and $\mathrm{K}$ fertilizers on durum wheat quality in different environments. Journal of Cereal Science 59: 9-14

Dupont F M, Hurkman W J, Vensel W H, Tanaka C, Kothari K M, Chung O K \& Altenbach S B (2006). Protein accumulation and composition in wheat grains: Effects of mineral nutrients and high temperature. European Journal of Agronomy 25: 96-107

Grausgruber H, Oberforster M, Werteker M, Ruckenbauer P \& Vollmann J (2000). Stability of quality traits in Austrian-grown winter wheats. Field Crops Research 66: $257-267$

Gray J A \& Bemiller J N (2003). Bread staling: Molecular basis and control. Comprehensive Review in Food Science \& Food Safety 2: 1-21

Graybosch R A, Peterson C J, Shelton D R \& Baenziger P S (1996). Genotypic and environmental modification of wheat flour protein composition in relation to enduse quality. Crop Science 36: 296-300

Huang D Y \& Khan K (1997). Quantitative determination of high molecular weight glutenin subunits of hard red spring wheat by SDS-PAGE. I. Quantitative effects of total amounts on bread-making quality characteristics. Cereal Chemistry 74: 781-785

Johansson E, Prieto-Linde M L, Svensson G \& Jönsson J Ö (2003). Influences of cultivar, cultivation year and fertilizer rate on amount of protein groups and amount and size distribution of mono-and polymeric proteins 
in wheat. The Journal of Agricultural Sciences 140: 275-284

Kim T D, Ryu H J, Cho H I, Yang C H \& Kim J (2000). Thermal behavior of proteins: Heat-resistant proteins and their heat-induced secondary structural changes. Biochemistry 39: 14839-14846

Landry J \& Moureaux T (1970). Heterogeneite des glutelines du grain de mais: Extraction selective et composition en acides amines des trios fractions isolees. Bulletin De La Societe De Chimie Biologique 52: 1021-1037

Merlino M, Leroy P, Chambon C \& Branlard G (2009). Mapping and proteomic analysis of albumin and globulin proteins in hexaploid wheat kernels (Triticum aestivum L.). Theoretical and Applied Genetics 18: 1321-1337

Panozzo J F \& Eagles H A (2000). Cultivar and environmental effects on quality characters in wheat. II. Protein. Crop Pasture Science 51: 629-636

Rhazi L, Graybosch R A \& Aussenac T (2014). Molecular characterization of three transgenic high molecular weight glutenin subunit events in winter wheat. Journal of Cereal Science 60: 631-638

Ribotta P D, Pérez G T, Añón M C \& León A E (2010). Optimization of additive combination for improved soy-wheat bread quality. Food Bioprocess Technology 3: $395-405$

Saint Pierre C, Peterson C J, Ross AS, Ohm J B, Verhoeven M C, Larson M \& Hoefer B (2008). Winter wheat genotypes under different levels of nitrogen and water stress: Changes in grain protein composition. Journal of Cereal Science 47: 407-416

Sayaslan A, Seib P A \& Chung O K (2006). Wet-milling properties of waxy wheat flours by two laboratory methods. Journal of Food Engineering 72: 167-178

Southan M \& MacRitchie F (1999). Molecular weight distribution of wheat proteins. Cereal Chemistry 76: 827-836

Triboi E, Abad A, Michelena A, Lloveras J, Ollier J L \& Daniel C (2000). Environmental effects on the quality of two wheat genotypes: 1.Quantitative and qualitative variation of storage proteins. European Journal of Agronomy 13: 47-64

Uthayakumaran S, Gras P W, Stoddard F L \& Bekes F (1999). Effect of varying protein content and gluteninto-gliadin ratio on the functional properties of wheat dough. Cereal Chemistry 76: 389-394

Uthayakumaran S, Listiohadi Y, Baratta M, Batey I L \& Wrigley C W (2006). Rapid identification and quantitation of high-molecular-weight glutenin subunits. Journal of Cereal Science 44: 34-39

Van Der Borght A, Goesaert H, Veraverbeke W S \& Delcour J A (2005). Fractionation of wheat and wheat flour into starch and gluten: Overview of the main processes and the factors involved. Journal of Cereal Science 41: 221-237

Welch R M (2005). Biotechnology, biofortification and global health. Food \& Nutrition Bulletin 26: 304-306

Whitney K, Ohm J B \& Simsek S (2014). Addition of glucose oxidase for the improvement of refrigerated dough quality. Cereal Chemistry 91: 548 - 553

Wilson J D, Bechtel D B, Wilson G W T \& Seib P A (2008). Bread quality of spelt wheat and its starch. Cereal Chemistry 85: 629-638

Wolf M J (1964). Wheat Starch Isolation. In: R Whistler (Ed), Methods in Carbohydrate Chemistry, Academic Press, London, pp. 6-9

Zhang P, He Z, Zhang Y, Xia X, Liu J, Yan J \& Zhang Y (2007). Pan bread and Chinese white salted noodle qualities of Chinese winter wheat cultivars and their relationship with gluten protein fractions. Cereal chemistry 84: 370-378

Zhu J \& Khan K (2001). Effects of genotype and environment on glutenin polymers and breadmaking quality. Cereal Chemistry 78: 125-130

Žilić S, Barać M, Pešić M, Dodig D \& Ignjatović-Micić D (2011). Characterization of proteins from grain of different bread and durum wheat genotypes. International Journal of Molecular Sciences 12: 5878-5894 